\title{
Tren, Tantangan, dan Perspektif dalam Sistem Logistik pada Masa dan Pasca (New Normal) Pandemik Covid-19 di Indonesia
}

\author{
Nova Indah Saragih ${ }^{1}$, Verani Hartati ${ }^{2}$, Muchammad Fauzi ${ }^{3}$ \\ 1,2,3) Fakultas Teknik, Program Studi Teknik Industri, Universitas Widyatama \\ Jl. Cikutra No. 204A, Bandung 40125 \\ Email: nova.indah@widyatama.ac.id, verani.hartati@widyatama.ac.id \\ 3) Logistics and Supply Chain Center, Universitas Widyatama \\ Jl. Cikutra No. 204A, Bandung 40125 \\ Email: muchammad.fauzi@widyatama.ac.id
}

\begin{abstract}
This paper discusses trends, challenges, and perspectives in logistics system of Indonesia during and post (new normal) of Covid-19 pandemic. PSBB (Large-Scale Social Restriction) caused a number of supply chains to be cut and made railroad transportation activities decreased. On the other hand, WFH (Work From Home) caused sector of e-Commerce to grow during the pandemic. Challenges in logistics system of Indonesia during the pandemic are changes in distribution patterns, changes in handling processes, changes in facilities and equipment, changes in business processes, and changes in networks. Adaptations in logistics system during the pandemic are using ICT (information and communication technology) such as TMS (Transportation Management System) and EDI (Electronic Data Interchange) and considering health. WMS (Warehouse Management System) still has a great opportunity to be utilized. The adaptations raise a new discipline in Industrial Engineering, namely logistics hygienic. The use of various ICTs in logistics system together with implementation of health protocols are expected to be a solution for logistics system in Indonesia, especially for the new normal of Covid-19 pandemic.
\end{abstract}

Keywords: Covid-19, health, hygienic logistics, ICT, logistics system

\begin{abstract}
Abstrak
Makalah ini membahas tren, tantangan, dan perspektif pada sistem logistik di Indonesia pada masa dan pasca (new normal) pandemik Covid-19. PSBB (Pembatasan Sosial Berskala Besar) menyebabkan terputusnya sejumlah rantai pasokan dan membuat kegiatan transportasi barang kereta api mengalami penurunan. Di sisi lain, WFH (Work From Home) menyebabkan sektor e-Commerce mengalami pertumbuhan pada masa pandemik. Tantangan pada sistem logistik di Indonesia pada masa pandemik antara lain perubahan pola distribusi, perubahan proses penanganan, perubahan fasilitas dan peralatan, perubahan proses bisnis, dan perubahan jaringan kerja. Adaptasi sistem logistik pada masa pandemik dilakukan dengan menggunakan ICT (information and communication technology) seperti TMS (Transportation Management System) dan EDI (Electronic Data Interchange), serta dengan mempertimbangkan kesehatan. WMS (Warehouse Management System) masih memiliki peluang yang besar untuk dimanfaatkan. Adaptasi ini memunculkan disiplin baru dalam ranah keilmuan Teknik Industri yaitu logistik higienis. Penggunaan berbagai ICT pada sistem logistik bersamaan dengan penerapan protokol kesehatan diharapkan dapat menjadi solusi bagi sistem logistik di Indonesia, khususnya pada masa new normal pandemik Covid-19.
\end{abstract}

Kata kunci: Covid-19, ICT, kesehatan, logistik higienis, sistem logistik 


\section{Pendahuluan}

WHO (World Health Organization) mengumumkan pandemik Covid-19 pada tanggal 11 Maret 2020. Pada tanggal tersebut, jumlah positif Covid-19 terkonfirmasi sekitar 121.000 kasus (Utomo, 2020). Sekitar sebulan kemudian, tanggal 13 April 2020, Presiden Joko Widodo secara resmi menetapkan Covid19 sebagai bencana nasional. Penetapan itu dinyatakan melalui Keputusan Presiden (Keppres) Republik Indonesia Nomor 12 Tahun 2020 tentang Penetapan Bencana NonAlam Penyebaran Corona Virus Disease 2019 (Covid-19) Sebagai Bencana Nasional (Sekretariat Kabinet Republik Indonesia, 2020a).

Sekitar tiga bulan setelah diumumkan sebagai pandemik (15 Juni 2020), jumlah kasus terkonfirmasi Covid-19 mencapai 7.690.708 kasus (WHO, 2020). Berdasarkan data dari Gugus Tugas Percepatan Penanganan Covid-19 (2020), kasus positif terkonfirmasi di Indonesia mencapai 38.277 kasus dengan jumlah korban meninggal sebanyak 2.134 kasus dan sembuh sebanyak 14.531 kasus. Sebaran kasus per provinsi dapat dilihat pada Gambar 1.

Untuk mempercepat penanganan pandemik Covid-19, Pemerintah Indonesia mengeluarkan sejumlah kebijakan yang dituangkan dalam peraturan. Di antaranya adalah Peraturan Pemerintah Republik Indonesia Nomor 21 Tahun 2020 tentang Pembatasan Sosial Berskala Besar dalam Rangka Percepatan Penanganan Corona Virus Disease 2019 (Covid-19) (Sekretariat Kabinet Republik Indonesia, 2020b). Teknis peraturan tersebut dituangkan dalam Peraturan Menteri Kesehatan Republik Indonesia Nomor 9 Tahun 2020 tentang Pedoman Pembatasan Sosial Berskala Besar dalam Rangka Percepatan Penanganan Corona Virus Disease 2019 (Covid-19) (Biro Hukum dan Organisasi Kementerian Kesehatan Republik Indonesia, 2020).

Pandemik Covid-19 dan peraturan yang lebih dikenal dengan PSBB (Pembatasan Sosial Berskala Besar) tersebut membawa sejumlah dampak pada sistem logistik di Indonesia. Gambar 2 merupakan tren pertumbuhan jumlah muatan angkutan kereta api barang Indonesia selama masa pandemik.

Sebagian besar kebijakan pembatasan pergerakan mengecualikan angkutan barang, namun beberapa hambatan seperti terputusnya rantai pasokan membuat kegiatan transportasi barang kereta api mengalami penurunan (Direktorat Jendral Perhubungan Darat, 2020).

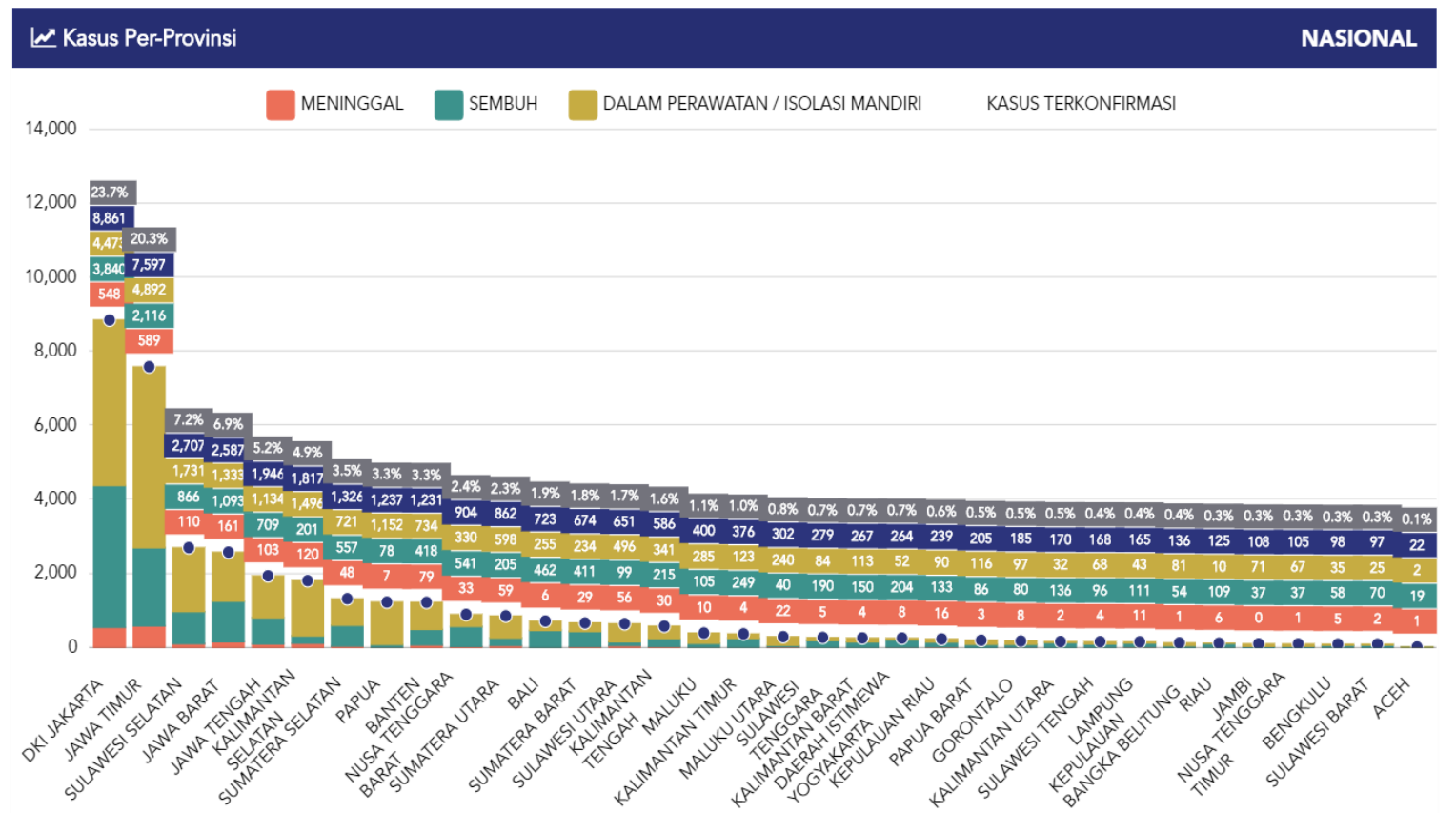

Gambar 1. Peta sebaran Covid-19 per provinsi Sumber: Gugus Tugas Percepatan Penanganan Covid-19 (2020) 


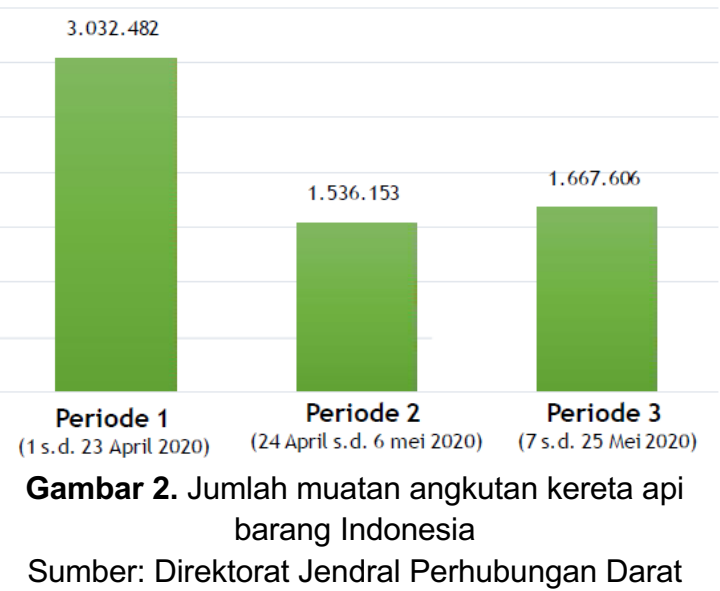

(2020)

Penurunan permintaan selama masa pandemik juga dialami oleh transportasi truk. Menurut Aptrindo (Asosiasi Pengusaha Truk Indonesia), penurunan permintaan tersebut mencapai 60\% (Mayasari, 2020). Demikian juga halnya dengan transportasi barang menggunakan laut yang mengalami penurunan pada periode Maret 2020 dan April 2020 sebesar $2,31 \%$. Volume angkutan barang laut pada bulan Maret 2020 adalah sebesar 25,49 ton, sedangkan pada bulan April 2020 adalah sebesar 24,91 ton (Azka, 2020a). Sama halnya dengan transportasi barang dengan moda udara. Menurut ALFI (Asosiasi Logistik dan Forwarder Indonesia), penurunan permintaan volume barang udara mencapai 15\% (Azka, 2020b).

Menurut definisi yang dikeluarkan oleh Council of Logistics Management dalam Ballou (1999), "logistics is that part of supply chain process that plans, implements, and controls the efficient, effective flow and storage of goods, services, and related information from the point of the origin to the point of the consumption in order to meet the customers' requirements". Bahagia (2020) selanjutnya memberikan definisi "logistik adalah disiplin yang berkaitan dengan pengelolaan aliran barang (flow of goods), aliran informasi (flow of information) dan aliran uang (flow of money) mulai dari pengadaan (procurement), penyimpanan (storage), dan penghantaran (delivery services) barang sesuai dengan jenis, jumlah, kualitas, waktu dan tempat yang dikehendaki konsumen dari titik asal (point of origin) ke titik tujuan (point of destination) secara efektif dan efisien.

Komponen-komponen dari sistem logistik menurut Council of Logistics Management dalam Ballou (1999), "the components of a typical logistics system are customer service, demand forecasting, distribution communications, inventory control, material handling, order processing, parts and service support, plant and warehouse site selection (locating analysis), purchasing, packaging, return goods handling, salvage and scrap disposal, traffic and transportation, and warehousing and storage". Komponenkomponen sistem logistik tersebut diilustrasikan pada Gambar 3.

Di lain sisi, sektor e-Commerce mengalami pertumbuhan pada masa pandemik. Menurut Direktorat Jendral Perhubungan Darat (2020), penjualan sektor e-Commerce meningkat $26 \%$ dari rata-rata bulanan tahun 2019, transaksi harian naik dari rata-rata 3,1 juta menjadi 4,8 juta, dan diperkirakan terjadi peningkatan pengguna belanja online sebanyak 12 juta pada tahun 2020.

ICT (Information and Communication Technology) yang paling umum digunakan dalam sistem logistik adalah LIS (Logistics Information System) atau sistem informasi logistik dan EDI (Electronic Data Interchange) atau pertukaran data elektronik (Javanovic \& Colovic, 2017).

Sistem informasi logistik memungkinkan interkoneksi dari semua partisipan di dalam rantai pasokan dan menciptakan peluang untuk pengelolaan yang efisien pada semua proses logistik. Teknologi dalam LIS antara lain IMS (Inventory Management System), TMS (Transportation Management System), dan WMS (Warehouse Management System).

Tujuan utama dari IMS adalah untuk menambah sistem yang ada dengan meningkatkan efisiensi dan efektivitasnya. Perangkat lunak meningkatkan metode kerja dengan mengganti sistem manual dengan sistem berbasis komputer. IMS mengotomatiskan setiap aktivitas dari sistem manual dan meningkatkan throughput-nya. Dengan demikian waktu respons sistem sangat sedikit dan kerjanya sangat cepat (Kumar, 2015).

Aplikasi TMS adalah alat yang dapat melakukan perencanaan, optimalisasi dan pelaksanaan kegiatan transportasi. Aplikasi TMS biasanya termasuk penawaran kargo, perutean, penjadwalan, pelacakan, pembayaran pengiriman, dan sistem audit (Cortes et al., 2013). 


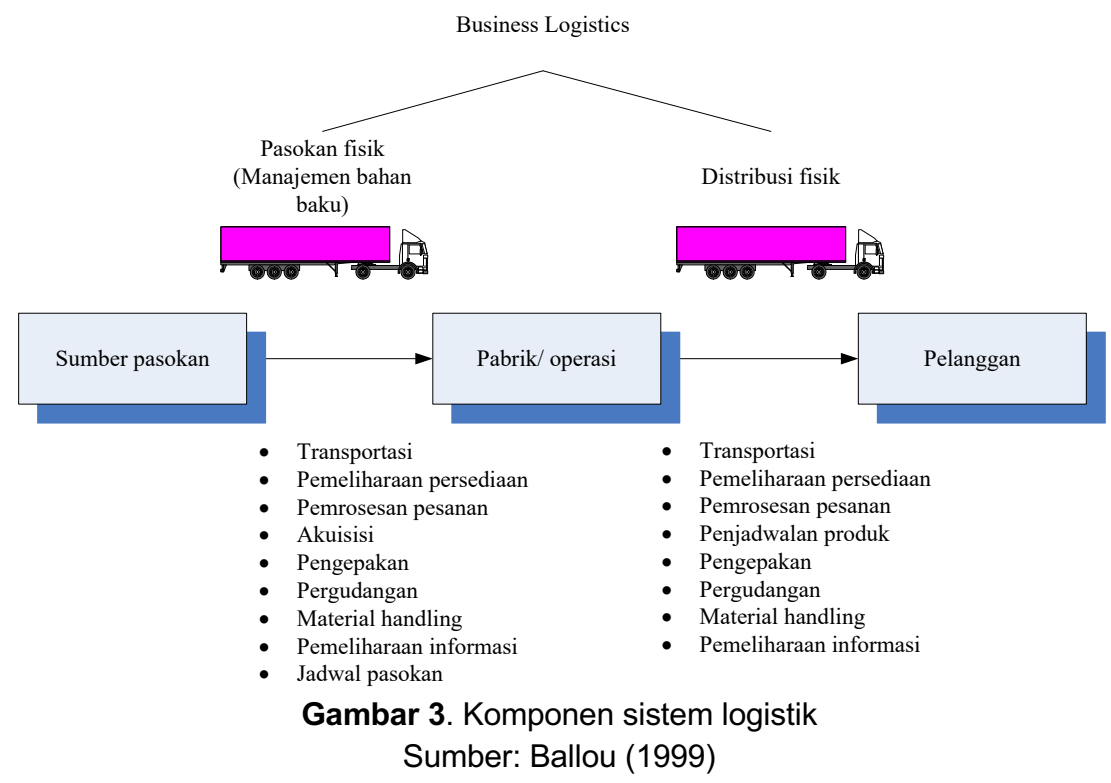

WMS dikhususkan untuk peningkatan efisiensi operasi pergudangan. Tujuan utama dari WMS adalah untuk melacak pergerakan, penyimpanan, dan penanganan barang di dalam sistem pergudangan. Dengan implementasi WMS, pengelolaan stok yang lebih baik dapat tercapai bersamaan dengan utilitas yang lebih baik dari kapasitas gudang serta realisasi yang lebih efisien dari operasi pergudangan.

Pertukaran data secara real time mampu meningkatkan keseluruhan produktivitas sebuah rantai pasokan yang mana perusahaan dapat menerima dan memproses informasi akurat dan tepat waktu terkait setiap pengiriman, pergudangan, SKU, dan sebagainya. Kerangka EDI mencakup semua aktor dalam sebuah rantai pasokan, mulai dari pemasok bahan mentah, produsen bahan setengah jadi, produsen barang jadi, dan konsumen akhir. Internet adalah aspek kunci untuk menjaga sistem EDI sebab partisipan di dalam rantai pasokan harus berkomunikasi secara konstan dan tepat waktu satu dengan yang lain.

EDI memungkinkan perusahaan untuk terhubung dengan pemasok dan konsumen dengan tujuan untuk mengintegrasikan keseluruhan aktivitas logistik. EDI menyediakan pertukaran data langsung melalui pengiriman elektronik yang menyederhanakan pembayaran melalui jaringan komunikasi data, kegiatan berdasarkan ongkos terkait informasi ongkos dari sumbernya, penomoran artikel dan penomoran batang untuk identifikasi barang serta akhirnya basis data untuk menyimpan, mengelola, dan menganalisis informasi yang terkumpul secara efisien (Javanovic \& Colovic, 2017).

Makalah ini selanjutnya bertujuan untuk membahas tren, tantangan, dan perspektif pada sistem logistik di Indonesia pada masa pandemik. Berdasarkan pembahasan tersebut dihasilkan solusi bagi sistem logistik di Indonesia, khususnya untuk masa new normal pandemik Covid-19.

\section{Metodologi}

Langkah-langkah penelitian dalam makalah ini dapat dilihat pada Gambar 4.

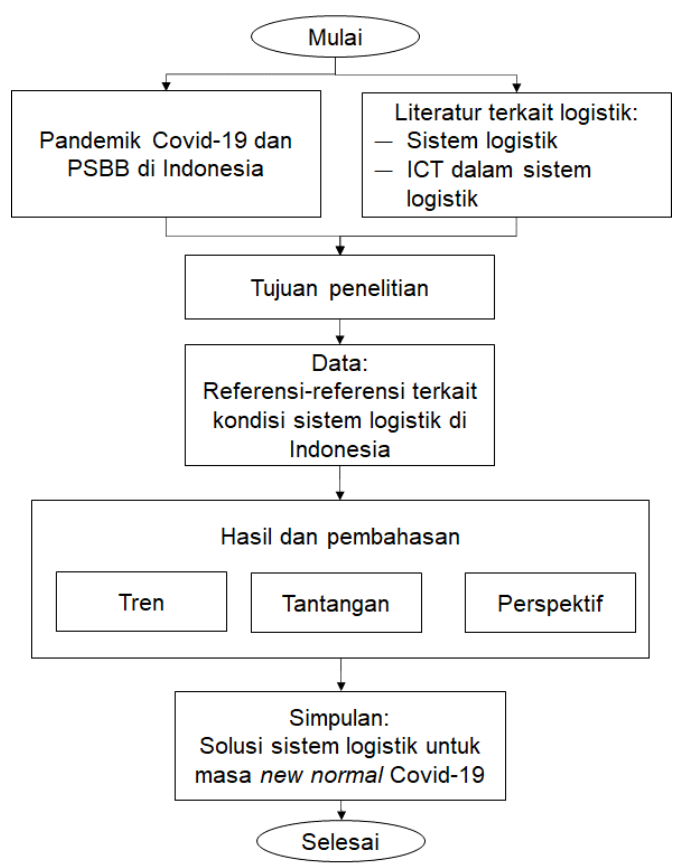

Gambar 4. Langkah-langkah penelitian 


\section{Hasil dan Diskusi}

\section{Tren Sistem Logistik}

Pandemik Covid-19 tidak hanya mengganggu sektor ekonomi dan bisnis, namun juga pergerakan logistik di Indonesia. Berbagai komoditas terhambat akibat PSBB karena pembatasan kegiatan di tempat atau fasilitas umum dan pembatasan moda transportasi, baik moda transportasi penumpang atau moda transportasi barang. Pembatasan kegiatan di tempat atau fasilitas umum selama PSBB membuat pemerintah mengeluarkan anjuran kepada para pelaku usaha untuk menjalakan program WFH (Work From Home) dan menutup fasilitas umum seperti pusat perbelanjaan dan pasar-pasar tradisional yang mengakibatkan turunnya daya beli masyarakat karena mobilitas yang dibatasi.

Menurut Boris Sanjaya selaku Chief Executive Officer Advotics mengatakan bahwa para pelaku usaha harus memastikan harga di ritel tetap wajar mengingat daya beli masyarakat ikut menurun dan yang paling utama adalah transparansi data dan digitalisasi untuk menghemat ongkos dengan memastikan jumlah produksi dan distribusi sejalan dengan permintaan (Fachrizal, 2020).

Menurut Danang Girindrawardana selaku Direktur Eksekutif Asosiasi Pengusaha Indonesia (APINDO) mengatakan bahwa dalam masa PSBB mekanisme rantai pasok akan terganggu jika tidak dikelola dengan baik dan akan membutuhkan waktu lama untuk diperbaiki, serta tidak akan selesai dalam enam bulan atau satu tahun ke depan (Yunianto, 2020).

Menurut Christine Natasya selaku Analis Mirae Asset Sekuritas, seperti contoh kasus pada perusahaan yang bergerak di sektor produksi rokok yang terganggu rantai pasoknya akibat penerapan PSBB di berbagai wilayah. Untuk mempertahankan underweight pada sektor produksi rokok diterapkan relaksasi penundaan pembayaran pita cukai rokok selama tiga bulan (Situmorang, 2020). Berbeda dengan strategi yang dilakukan oleh Pertamina. Pertamina memastikan kelancaran pasokan dan distribusi energi selama PSBB berlangsung. Bahkan pihak Pertamina meningkatkan layanan masyarakat dengan memaksimalkan layanan pesan antar dengan program PDS (Pertamina Delivery Service) untuk mendukung program \#DiRumahAja dengan tetap memperhatikan protokol pencegahan penularan Covid-19. Menurut Fajriyah Usman selaku Vice President Corporate Communication Pertamina mengatakan bahwa inovasi ini dapat dirasakan oleh para pelanggan dengan menghubungi langsung kontak Pertamina 135 atau melalui pesan Whatsapp ke 08111350135 mulai pukul 08.00 hingga pukul 22.00. Kurir PDS dilengkapi alat pelindung diri dan alat kebersihan akan mengantarkan langsung pesanan pelanggan (Pertamina, 2020).

\section{Tantangan Sistem Logistik}

Menurut Setijadi (2020), dampak pandemik Covid-19 antara lain adalah perubahan daya beli masyarakat, perubahan gaya hidup, perubahan kebutuhan pasokan, perubahan pola perdagangan, perubahan regulasi dan kebijakan, dan perubahan volume barang. Sejumlah perubahan tersebut membawa tantangan pada sistem logistik di Indonesia yaitu:
a. Perubahan pola distribusi
b. Perubahan proses penanganan
c. Perubahan fasilitas dan peralatan
d. Perubahan proses bisnis
e. Perubahan jaringan kerja

Rekomendasi untuk menjawab sejumlah tantangan dalam sistem logistik tersebut antara lain adalah:

1. Infrastruktur

a. Integrasi dengan rencana induk pengembangan konektivitas (infrastruktur) logistik nasional

b. Penyiapan infrastruktur dan fasilitas penanganan logistik berbasis produk/komoditas

2. Produk/komoditas

a. Pengembangan pusat konsolidasi produk/komoditas berkaitan dengan ketersebaran produksi dan skala ekonominya

b. Pengembangan produk/komoditas dan industri lokal/daerah untuk menyeimbangkan volume pengiriman antarwilayah

c. Peningkatan daya saing, kontinuitas, dan standardisasi produk/komoditas

3. Penyedia jasa logistik

a. Peningkatan pemahaman terhadap produk/komoditas dan rantai pasoknya 
b. Peningkatan pengelolaan

kemampuan (people, process, technology)

c. Penguatan proses, fasilitas, dan pelaku konsolidasi produk/komoditas

d. Efisiensi (pengurangan panjang) rantai pasok produk/komoditas

e. Standardisasi dan integrasi proses bisnis antar penyedia jasa logistik

f. Adaptasi perubahan pola bisnis dan perdagangan

g. Perencanaan dan implementasi Sistem Manajemen Risiko

4. Regulasi dan birokrasi

a. Integrasi perencanaan, pemantauan, dan evaluasi rantai pasok produk/komoditas

b. Dukungan kebijakan dan regulasi pusat dan daerah

c. Koordinasi antar kementerian/lembaga maupun antara pemerintah pusat dan pemerintah daerah

d. Adaptasi perubahan pola
perdagangan dan teknologi

5. Sistem informasi

a. Integrasi sistem informasi rantai pasok produk/komoditas

b. Integrasi sistem informasi dalam jaringan transportasi

\section{Perspektif Sistem Logistik}

Terdapat sejumlah perspektif dalam sistem logistik terkait pandemik Covid-19. Salah satunya adalah dengan beradaptasi (Bahagia, 2020). Adaptasi dilakukan dengan menggunakan information and communications technology (ICT). Hal tersebut sejalan dengan apa yang disampaikan oleh Direktorat Jendral Perhubungan Darat (2020). Digitalisasi pada pelanggan, produk, dan manajemen sangat penting untuk dapat beradaptasi pada masa pandemik seperti yang telah dibuktikan oleh sektor e-Commerce.

Petani sayur dan buah yang beralih dari penjualan langsung ke konsumen (pasar tradisional, hotel, restoran, dan sebagainya) ke penjualan daring menggunakan e-Commerce adalah salah satu contoh penggunaan teknologi pada masa pandemik. Tanpa penggunaan teknologi, maka barang tidak akan sampai ke konsumen dikarenakan adanya pembatasan sosial (Harper, 2020). Platform e-Commerce yang ada di Indonesia adalah Tokopedia, Bukalapak, Lazada,
Shopee, JD ID, dan Blibli. Dengan menggunakan platform e-Commerce, produsen dapat menerima dan memproses informasi akurat dan tepat waktu terkait setiap pembelian, pengiriman, pergudangan, SKU, dan sebagainya. Demikian juga dengan kemudahan dalam proses pembayaran, yang melibatkan pihak perbankan, juga disediakan oleh platform e-Commerce. ICT yang disediakan oleh e-Commerce tersebut termasuk ke dalam EDI.

ICT yang digunakan untuk mengirimkan barang ke konsumen pada masa pandemik termasuk ke dalam teknologi TMS. TMS digunakan untuk menjadwalkan dan melacak barang pada saat dikirimkan. Teknologi ini secara umum digunakan oleh penyedia jasa logistik, seperti Pos Indonesia, JNE, J\&T, dan SiCepat Ekspres. Teknologi TMS yang lebih maju, yang dapat menentukan rute, digunakan oleh GoSend dan GrabExpress.

Selain menggunakan ICT, adaptasi pada masa pandemik juga mempertimbangkan kesehatan untuk mencegah penularan Covid19. Hal tersebut disebabkan karena aktivitas pada sistem logistik tidak dapat sepenuhnya dilakukan secara digital (Gambar 3). Protokol pencegahan penularan Covid-19 pada sistem logistik mengacu pada Surat Edaran Menteri Kesehatan Nomor 216 Tahun 2020 tentang Protokol Pencegahan Penularan Coronavirus Disease (Covid-19) di Tempat Kerja (Kementerian Kesehatan, 2020). Salah satu protokol pencegahan penularan Covid-19 pada angkutan barang adalah pembatasan jumlah orang di dalam angkutan barang yang hanya terdiri dari pengemudi dan pembantu pengemudi (Direktorat Jendral Perhubungan Darat, 2020).

Adaptasi sistem logistik dengan menggunakan ICT dan mempertimbangkan kesehatan tersebut memunculkan disiplin baru dalam ranah keilmuan Teknik Industri yaitu logistik higienis (hygienic logistics). Disiplin tersebut ditemukan oleh Bahagia (2020). Logistik higienis adalah disiplin yang berkaitan dengan pengelolaan aliran barang higienis (flow of hygienic goods), aliran informasi (flow of information), dan aliran uang (flow of money) mulai dari kegiatan pengadaan (procurement/trade), penyimpanan (storage), dan pengantaran (delivery services) barang sesuai dengan jenis, jumlah, kualitas, waktu dan tempat yang dikehendaki konsumen dari 


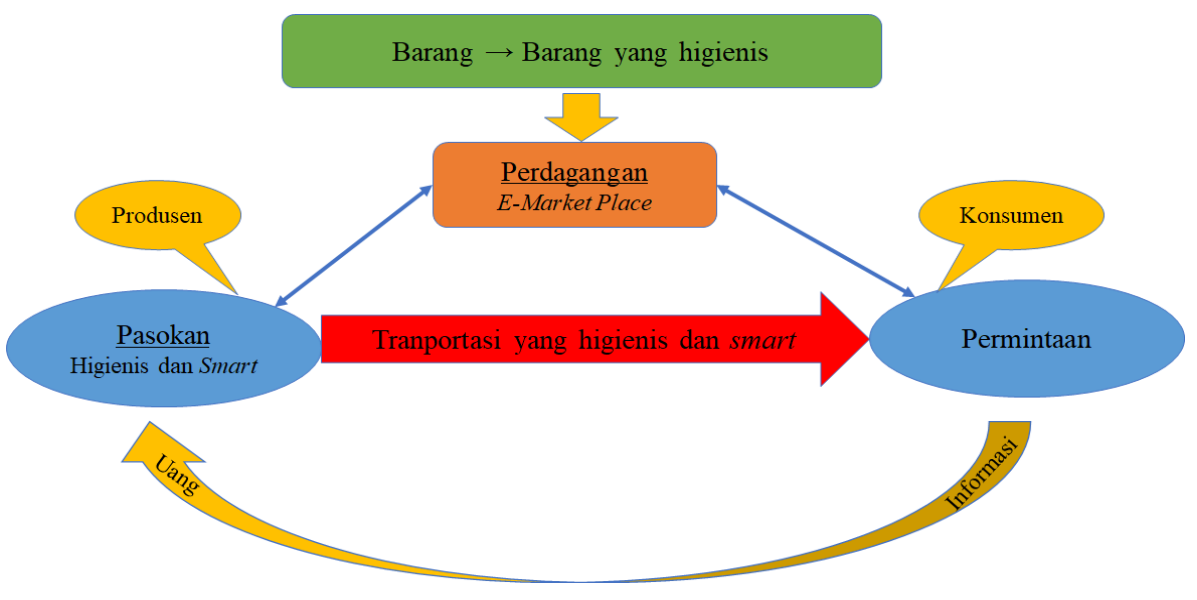

Gambar 5. Ilustrasi logistik higienis Sumber: Bahagia (2020)

titik asal (point of origin) ke titik tujuan (point of destination) secara efektif dan efisien dengan mengaplikasikan prinsip sehat dan menyehatkan. Ilustrasi dari logistik higienis dapat dilihat pada Gambar 5.

Karakteristik dari logistik higienis diberikan pada Tabel 1. Disiplin ilmu ini membuka peluang penelitian-penelitian baru untuk ke depannya.

\section{Kesimpulan}

Berdasarkan pembahasan sebelumnya, dapat diketahui bahwa ICT yang digunakan dalam sistem logistik di Indonesia pada masa pandemik adalah TMS dan EDI. TMS digunakan oleh penyedia jasa logistik untuk mengirimkan barang dari produsen ke konsumen. Produsen menggunakan platform e-Commerce untuk melakukan proses perdagangan dengan konsumen dan memanfaatkan teknologi EDI dalam prosesnya. ICT yang lain, khususnya WMS masih memiliki peluang yang besar untuk dimanfaatkan.

Para penyedia jasa logistik dapat memanfaatkan WMS untuk mencapai utilitasi yang lebih baik dari kapasitas gudang dan operasi pergudangan yang lebih efisien melalui penggunaan gudang bersama. Penggunaan gudang bersama ini juga akan meningkatkan utilitas kendaraan dan mengurangi jumlah kendaraan yang digunakan. Penggunaan berbagai ICT pada sistem logistik bersamaan dengan penerapan protokol kesehatan diharapkan dapat menjadi solusi bagi sistem
Tabel 1. Karakteristik logistik higienis

\begin{tabular}{|c|c|c|c|}
\hline No. & $\begin{array}{l}\text { Aktivitas } \\
\text { logistik }\end{array}$ & Karakteristik & Remark \\
\hline 1 & Barang & Higienis & $\begin{array}{l}\text { Bahan } \\
\text { mentah } \\
\text { dan } \\
\text { produk } \\
\text { jadi }\end{array}$ \\
\hline 2 & Misi & $\begin{array}{l}7 \text { Rs (right product, } \\
\text { right customer, } \\
\text { right time, right } \\
\text { place, right } \\
\text { condition, right } \\
\text { quantity, right cost) } \\
+ \text { higienis }\end{array}$ & \\
\hline 3 & Pengadaan & $\begin{array}{l}\text { Pengadaan yang } \\
\text { higienis dan smart }\end{array}$ & $\begin{array}{l}\text { Nilai } \\
\text { terbaik } \\
\text { dari uang } \\
\end{array}$ \\
\hline 4 & Produksi & $\begin{array}{l}\text { Smart GMP (good } \\
\text { manufacturing } \\
\text { product) + higienis }\end{array}$ & $\begin{array}{l}\text { Produktif, } \\
\text { efisien, } \\
\text { dan } \\
\text { higienis }\end{array}$ \\
\hline 5 & $\begin{array}{l}\text { Persediaan } \\
\text { dan } \\
\text { pergudang- } \\
\text { an } \\
\end{array}$ & Zero inventory & $\begin{array}{l}\text { No } \\
\text { warehous- } \\
\text { ing }\end{array}$ \\
\hline 6 & $\begin{array}{l}\text { Transporta- } \\
\text { si }\end{array}$ & $\begin{array}{l}\text { Transportasi } \\
\text { higienis dan smart }\end{array}$ & $\begin{array}{l}\text { Pengirim- } \\
\text { an yang } \\
\text { andal dan } \\
\text { cepat }\end{array}$ \\
\hline 7 & $\begin{array}{l}\text { Layanan } \\
\text { pelanggan }\end{array}$ & e-Market place & $\begin{array}{l}\text { Layanan } \\
\text { pelangg- } \\
\text { an yang } \\
\text { efisien }\end{array}$ \\
\hline 8 & Informasi & & $\begin{array}{l}\text { Andal, } \\
\text { akurat, } \\
\text { dan } \\
\text { timeless }\end{array}$ \\
\hline 9 & Sistem & Push system & $\begin{array}{l}\text { Pull } \\
\text { system }\end{array}$ \\
\hline
\end{tabular}

Sumber: Bahagia (2020) 
logistik di Indonesia, khususnya pada masa new normal pandemik Covid-19.

\section{Daftar Pustaka}

Azka, R. M., Volume Angkutan Barang via Laut Bisa Terus Menanjak di Tengah Pandemi Covid-19, [Online], Diakses dari: https://ekonomi.bisnis.com/read/20200603/ 98/1247757/volume-angkutan-barang-vialaut-bisa-terus-menanjak-di-tengahpandemi-covid-19 [2020a, 7 Juli].

Azka, R. M., ALFI Beberkan Kondisi Kargo Udara di Tengah Pandemi, [Online], Diakses dari: https://ekonomi.bisnis.com/read/20200503/ 98/1235753/alfi-beberkan-kondisi-kargoudara-di-tengah-pandemi [2020b, 7 Juli].

Bahagia, S. N. (2020). Optimalisasi Sistem Logistik Pada Masa dan Pasca Pandemik Covid-19. Webinar Transportasi dan Logistik Saat dan Pasca Pandemi Covid-19 di Indonesia. (Jakarta, 10 Juni 2020).

Ballou, R.H. (1999). Business Logistics Management. USA: Prentice Hall.

Biro Hukum dan Organisasi Kementerian Kesehatan Republik Indonesia, Produk Hukum, [Online], Diakses dari: http://hukor.kemkes.go.id/uploads/produk_h ukum/PMK_No_9_Th_2020_ttg_Pedoman _Pembatasan_Sosial_Berskala_Besar_Dal am_Penanganan_COVID-19.pdf [2020, 15 Juni].

Cortes, J. A. Z., Serna, M. D. A., \& Gomez, R (2013). Information Systems Applied To Transport Improvement. Dyna rev.fac.nac.minas, Medellín, 80, 77-86.

Direktorat Jendral Perhubungan Darat. (2020). Tantangan Industri Logistik Dalam Masa Pandemi COVID-19. Webinar Transportasi dan Logistik Saat dan Pasca Pandemi Covid-19 di Indonesia. (Jakarta, 10 Juni 2020).

Fachrizal, R., Advotics Berbagi Cara Menyiasati Rantai Pasok Bisnis di Saat Pandemi, [Online], Diakses dari: https://infokomputer.grid.id/read/122116070 ladvotics-berbagi-cara-menyiasati-rantaipasok-bisnis-di-saat-pandemi?page=all [2020, 15 Juni].

Gugus Tugas Percepatan Penanganan Covid19, Peta Sebaran, [Online], Diakses dari: https://covid19.go.id/peta-sebaran [2020, 15 Juni].
Harper, Z., Virus Corona: Siasati 'Lockdown', Petani Indonesia Dan Negara-Negara Asia Rambah Pasar Digital, [Online], Diakses dari:

https://www.bbc.com/indonesia/majalah52892096?at_custom1=\%5Bpost+type $\% 5 \mathrm{D}$ \&at_campaign $=64 \&$ at_medium $=$ custom $7 \& a$ t_custom2=twitter\&at_custom $3=B B C+$ Indon esia\&at_custom4=99D55396-A795-11EAA105-CCEF923C408C [2020, 7 Juli].

Javanovic, I. \& Colovic, A. (2017). ICT in Logistics: Possibilities and The Areas of Application. $3^{\text {rd }}$ Logistics International Conference. (Belgrade, 25-27 May 2017).

Kementerian Kesehatan, Peraturan, [Online], Diakses dari: https://infeksiemerging.kemkes.go.id/downl oads/?dl_page $=1 \& d l$ cat $=3 \# . X u 3 A p 2 g z Y 2$ w [2020, 15 Juni].

Kumar, N. (2015). Inventory Management System. International Journal of Innovative Research in Technology, 2, 280-285.

Mayasari, S., Ada Corona, Permintaan Jasa Truk Anjlok Hingga 60\%, [Online], Diakses dari: https://industri.kontan.co.id/news/adacorona-permintaan-jasa-truk-anjlok-hingga60 [2020, 7 Juli].

Pertamina, Pertamina Energi Weekly, [Online], Diakses dari: https://www.pertamina.com/Media/File/Ener gia-Weekly-20-April-2020.pdf [2020, 15 Juni].

Sekretariat Kabinet Republik Indonesia, Presiden Tetapkan Bencana Nonalam Penyebaran Covid-19 sebagai Bencana Nasional, [Online], Diakses dari: https://setkab.go.id/presiden-tetapkanbencana-nonalam-penyebaran-covid-19sebagai-bencana-nasional/ [2020a, 15 Mei].

Sekretariat Kabinet Republik Indonesia, Produk Hukum, [Online], Diakses dari: https://jdih.setkab.go.id/PUUdoc/176085/PP _Nomor_21_Tahun_2020.pdf [2020b, 15 Mei].

Setijadi, Mengatasi Persoalan Angkutan Logistik di Tengah Pandemi, [Online], Diakses dari: https://www.askara.co/read/2020/06/13/551 5/mengatasi-persoalan-angkutan-logistik-ditengah-pandemi [2020, 15 Juni].

Situmorang, R. T., Kinerja Emiten Rokok Diestimasi Tersudut Penerapan PSBB, [Online], Diakses dari: https://m.bisnis.com/amp/read/20200429/18 
9/1234569/kinerja-emiten-rokok-diestimasitersundut-penerapan-psbb [2020, 15 Juni].

Utomo, A. P., WHO Umumkan Virus Corona sebagai Pandemi Global, [Online], Diakses dari: https://www.msn.com/id$\mathrm{id} /$ berita/dunia/who-umumkan-virus-coronasebagai-pandemi-global/ar-BB113bKq [2020, 15 Mei].

WHO, Coronavirus Disease (COVID-19) Outbreak Situation, [Online], Diakses dari: https://www.who.int/emergencies/diseases/ novel-coronavirus-

2019?gclid=Cj0KCQjw2PP1BRCiARIsAEqv -pTjzJ-ELeuvdZ0zo65DCbG-

ZeOXhNUufG_I2dlaKGvJQXW4jMKFBBYa

AuqbEALw_wcB [2020, 15 Juni].
Yunianto, T. K., Pengusaha Sebut Gangguan Rantai Pasok Akibat PSBB Sulit Pulih, [Online], Diakses dari: https://katadata.co.id/berita/2020/04/14/pen gusaha-sebut-gangguan-rantai-pasokakibat-psbb-sulit-pulih [2020, 15 Juni].

\section{Ucapan Terima Kasih}

Penulis mengucapkan terima kasih kepada Kementerian Riset dan Teknologi/Badan Riset dan Inovasi Nasional atas Hibah Penelitian Dosen Pemula (PDP) Tahun 2020 dengan Nomor Kontrak: 012/SP4/LP2MUTAMA/VI/2020. 
DOI: https://doi.org/10.26593/irsi.v9i2.4009.77-86

Halaman ini sengaja dikosongkan.

This page is intentionally left blank. 